\title{
The Translation of Jihad Verses After the Emergence of ISIS: Distortion or Reality ${ }^{1}$
}

\author{
Anjad A. Mahasneh \\ Associate Professor, Translation Department, \\ Yarmouk University, Shafiq Irshidat st., Irbid, Jordan
}

DOI: https://doi.org/10.36941/ajis-2021-0128

\begin{abstract}
The mistranslation, misinterpretation and misquotation of Quranic verses, particularly jihad verses by radicalists reflect an extreme misunderstanding of Islam for being an abusive and violent religion. Thus, this study examines three groups of books, reflecting the attitude towards Islam, jihad, Quran, and radicalist groups. Group one represents western authored books published in 2014 and after (the emergence of ISIS period); group two, presenting Arab and Muslim-authored books; and finally, group three includes books for Western authors which were published before 2014. Three groups scrutinize jihad and war related verses, the conception of jihad, some names of Islamist figures, and stereotypes of Islam. Jihad verses and their interpretations and translations were extracted from those books and compared to their true tafsir and reasons of revelations according to Ibn Katheer tafsir. The results revealed that interpreting and translating Quranic verses out of their context by radical groups especially ISIS to justify their awful deeds has participated largely in increasing the hostility of western authors and western media towards Islam and Muslims and raised Islamophobia internationally.
\end{abstract}

Keywords: Jihad, Quranic Verses, Qital, Islam, Mistranslation, Misinterpretation, ISIS

"And as all True Islam forbids wanton aggression and terrorism, enjoins freedom of religion, peace, justice and good-will to non-Muslims, it is also a message of good news, friendship and hope to the whole world" Abdullah II bin Al-Hussein, Amman Message 2006

\section{Introduction}

The wide acceptance in Western public opinion of the idea that Arabs and Muslims embrace terrorism did not appear suddenly, yet it has acquired a high level of intensity during the long-tense history between the West and the Arab and Islamic worlds (Ridouani, 2011; Mešić, 2004). However, some radical movements and terrorist militias have begun to implement their agendas by taking advantage of the misinterpretation of Quranic and Islamic principles. This has generated increased negative attitudes toward Islam, in the West and globally, by portraying Muslims as terrorists and implying that any incidents are a result of their religion. 
Regrettably, recent political events and the rising threat of extremist groups that have ascribed their deeds to jihad have paved the road to the emergence of the concept of jihadism, a novel term derived from jihad, which has captured the attention of the media and politicians. Many scholars see jihadism as more than an ideology adopted by extremist groups, who espouse jihad as an instrument for achieving political gains(Ramakrishna, 2005; Bunzel, 2017; Abdullah 2007), but rather as "a distinct movement, one not only discernable but also conscious and even proud of its separateness" (Bunzel, 2017: 11).

Though these extremist groups and the jihadist ideology they advocate have no specific targetsMuslims and non-Muslims are targeted alike-Muslims are the most affected. Terrorist groups use their own extreme interpretations and misquotations of jihad and the qital verses of the Quran to justify their extreme conduct. "One way violent Islamists attempt to generate support among fellow Muslims is through appealing to a sense of grievance," which gives rise to the idea that "Muslims and Islam are under threat and need to be defended through violent jihad" (Cherney \& Murphy, 2019: 1050), and, subsequently, that it is fair to ascribe their terrorist activities to Islam. Thus, comprehensive and logical efforts are required to raise awareness of the idea that terrorism is a tactic and an ideology, not a religion. There is an urgent need to refute the faulty-trio concept of terrorism, Islam, and jihad that constrains the public perception of these ideas as united phenomena, causing dissociation and rifts inside communities and resulting in riots, hatred, racism, denial of social pluralism, and terrorist attacks among social parties and races.

During this time, part of the Western media had "produced a tradition of portraying, in largely negative and self-serving ways, the Islamic religion and Muslim cultures" (Ridouani, 2011: 10) influencing these stereotypes despite the changes of interests and motivations in the on-going relationship between the two worlds (ibid). The negative coverage of Islam and Muslims began shortly after the September 11 attacks and has expanded in the past years following the rise of ISIS, a group whose growth and influence have been bolstered by such distortions and misrepresentations.

An old-new argument about jihad and the Quran has consequentially started to rise to the surface of this discourse: Quranic verses calling for jihad have been mistranslated and misinterpreted out of context to amplify the gap between Islam and the rest of the world. The present study sheds light on the "true" interpretation of such verses, how some Western literature has distorted the image of a peaceful Islam, and how we can bridge this gap by correcting the interpretation of such verses and images since "Muslims, and early Muslim translators, have, perhaps rightly, looked upon these translations with suspicion, as parts of a larger hostile, missionary project" (Svensso, 2019: 225). In the current context of the turmoil in the Middle East and Arabic region; the war within Islam itself following the emergence of ISIS/Daesh; and the outlaws of Islam, the Khawarij, this qualitative analysis of jihad and war-related Quranic verses provides new definitions of the misinterpretation, misquotation, and mistranslation of these verses and the Quran as a whole, paving the way to further examination of the abuse of Quranic verses. Further, although previous literature has discussed Islamophobia, ISIS, Jihad among others, the comparison of the misinterpretation of jihad verses by Western literature after 2014 (the emergence of ISIS) has not yet been fully addressed.

\section{Materials and Experimental Procedures}

A total of 66 books were investigated for this study. A search was carried out on the Amazon website to find the best-selling books that discuss jihad, ISIS, and the image of Islam to examine their ideas, attitudes, and use of jihad and war-related Quranic verses in these books, as well as to highlight on the misinterpretation, misquotation, and mistranslation of these verses. The total ratings of the selected books on Amazon Website forms 4 stars rating. Each one of the verses of interest was extracted, along with their contexts and interpretation, from the examined books and were then compared to their description and reasons of revelation in the Ibn Katheer interpretation. The Ibn Katheer interpretation (Tafseer al-Qur'ān al-'Azeem) was used because it is one of the most comprehensive, famous, most widely cited, and complete explanations and commentaries of the 
Quran. Ten books proved to be irrelevant, even though their titles were related to the topic of this project and were therefore excluded from the analysis. The remaining books were divided into three groups and focused on the following topics of concern: terrorism, jihad, jihadism and Islamic militancy, Salafism, Islamism, radical and terrorist groups, Islam and the Middle East, images of Islam, and Islamophobia.

Group One included 37 books presenting an average of a 3.8-star rating on Amazon, they were published from 2014 (coinciding with the expansion and rise in awareness of ISIS) and were written by Western authors of which 18 from the USA, 18 from the UK, and one from Germany. Group Two included 12 books written both before and after 2014 by Muslim and Arab authors about the same topic; 5 were published in the USA and 7 in the UK. Group Three included 7 books which were written before 2014, but also by Western authors; 4 were published in the USA, 2 in the UK, and one in Singapore. Those books were selected to highlight any differences in the degree of hostility towards Arabs and Muslims and the number of jihad verses that were taken out of context following the rise in the international awareness of ISIS.

It is necessary to point that books of group one represents the main core of the this research which is to highlight on the most popular books after the emergence of ISIS and to study conception of Islam and jihad reflected and influenced by the ideology and actions of ISIS and what image formed as a result of terrorist acts justified by ISIS through their Tafseer of Quranic verses hence the concept of jihad. While group two and three studied to take a look at the idea that had been presented about Islam and jihad before the emergence and the effect of ISIS, referring to the books of group three, and the opinion of Arab and Muslim authors about the same topic before and after ISIS, as found in group two. All the Quranic verses mentioned in these books, particularly those where the concepts of jihad or qital were mentioned within a war-related context, were extracted and studied.

\section{Results and Findings}

Before diving to the findings of the study it is important to discuss the translation of the Holy Quran. Thus, translating the Quran is a thorny task and a resort to a trusted exegesis is required. Any translation can only cover the meaning of the Quran, not an interpretation of the Quran itself. This hints that the "untranslatability [of the Quran] may be one reason why translations, as data in themselves, have received little attention in the field of Islamic studies, at least when compared with the source text" (Svensson, 2019: 211) All this led to the conclusion that the mistranslation or misinterpretation of some Quranic verses and concepts, such as jihad, are particularly possible when undertaken by non-experts who are occupied and affected by the savage actions of terrorist groups such as ISIS. Therefore, this could have affected the understanding of jihad by group one books authors and consequently affects their opinions about it and this could explain this hostility against the concept of jihad in particular and Islam in general.

\subsection{Examples of Misinterpretation/mistranslation/misquotation of jihad verses}

Opinions on jihad and war verses thus varied among the authors of the examined books, though centered on similar ideas, including that jihad and qital are parallel to each other, that jihad is a warrelated and violent term, the reality of the relationship between Muslims and non-Muslims, and that the historical path of Islam has had a huge impact on the development of the notion of war and jihad. Authors in all three groups cited multiple verses and discussed them differently, however, some verses were subject to misquotation, misinterpretation, and mistranslation.

The jihad-related verses cited by the three groups presented several arguments, namely the nature of the relationship between Muslims and non-Muslims, the law of war and use of force, Islam as a religion of violence or peace, and the ideology of Islamist extremism and radicalism, with ISIS at forefront of this movement. Verses such as 9:5, 9:29, 2:190-193 were the most frequently cited among the three groups. Consider the following examples from the three groups with a special focus on 
group one, the meat of this study:

Group One authors interpreted and translated jihad as the use of force in the name of God and religious action against non-Muslims. They assumed that the Quran is the source of authoritative commands to fight and kill disbelievers wherever they are found. Furthermore, some authors from Group One cited portions of verses and phrases out of context to illustrate and prove their arguments that the divine commands in the Quran instruct Muslims to execute disbelievers.

\subsubsection{Example One (out of context):}

Evans and Johnston (2015: 81) opted to quote part of verse 47:4 out of its context: "When you meet the unbelievers, smite their necks", stating that the Quran presents many violent statements that command Muslims to kill infidels and disbelievers. However, the full verse reads as follows:

"So when you meet those who disbelieve [in battle], strike [their] necks until, when you have inflicted slaughter upon them, then secure their bonds, and either [confer] favor afterward or ransom [them] until the war lays down its burdens. That [is the command]. And if Allah had willed, He could have taken vengeance upon them [Himself], but [He ordered armed struggle] to test some of you by means of others. And those who are killed in the cause of Allah - never will He waste their deeds". (47:4).

It is evident that the main point Evans and Johnston (2015) wanted to prove here was that Quranic verses include some forms of violence in their commands towards non-Muslims. Nevertheless, the revelation of this verse in fact dates back to the battle of Badr, which was the first armed encounter between Muslims, after migration to Medina, and the idolaters of Mecca, the Quraish. This tribe oppressed, killed, and further made life difficult for Muslims, hijacking their goods and stealing their caravans. In this battle, Muslims were ordered that, whenever they met these unbelievers in battle, they should fight them, cut them down with their swords, and take prisoners of war to deter them from transgressing over Muslims again. However, Muslims were also instructed that whenever the war ended, they should be generous to these prisoners and set them free without any charge and ransoms.

In the same context, multiple authors from Group two examined the ideology of radical and Islamist fundamentalists who have abused the Quran's verses by misquoting and selectively citing parts of verses or even whole verses out of context to add a more religious and legitimate justification to their actions. Moreover, such radicals have also used these misquotations to create an ideological and religious foundation from which to establish a violent mindset that other terrorists can then adopt to justify their crimes in the name of Islam (Euben \& Zaman, 2009; Tibi, 2014; Amin, 2015).

In reviewing Bin Laden's misquotation methodology, one of Group Three's authors, Amin, mentioned that Bin Laden had selectively used parts of verses to present a different interpretation of them according to his own agenda, and considered this a form of "removing phrases that qualify how these verses should be understood" (Amin, 2015 120).

\subsubsection{Example two (selective quotation):}

An example of verses misquoted by Bin Laden, which were used to justify attacks against the West and whoever supported it, was, "Fight them until there is no more persecution and until worship is devoted to God." He did not cite the remainder of the verse, though, which states:

"If they cease hostilities, there can be no [further] hostility, except towards aggressors" (2:193).

\subsubsection{Example three (partial quotation):}

Another verse partially quoted by Bin Laden was 16:126, which states: 
"And if you punish [your enemy, O you believers in the Oneness of God], punish them with the like of that with which you were afflicted," however, the qualifying part of this verse instructs, "...but it is best to show patience."

\subsubsection{Example four (misinterpretation and mistranslation):}

It is important to examine the common views on the most frequently mentioned verse, (9:5) as an example of misquotation, misinterpretation, and mistranslation;

"When the sacred months have passed slay the idolaters wherever you find them, and take them, and confine them and lie in wait for them at every place of ambush".

The three groups shared the same opinion when discussing this controversial verse (the verse of the sword), which expresses a violent statement according to some authors. It was commonly seen as a verse that rejects coexistence with non-Muslims and urges killing them, thus creating a justification for using force against non-Muslims by Islamist extremists. Nevertheless, the extent to which this verse was exemplified in this context was seen more frequently in Group One, whose authors were writing following the expansion of ISIS and growing awareness of the organization in the West. In Group Two the verse was mentioned as an instance of terrorist groups' misquotation that leads to the misunderstanding and abuse of Quranic content in the course of terrorist agendas. Group Three's authors, who wrote pre-2014, discussed and cited this verse less frequently, except Spencer, who also used the verse to exemplify the violent call of the Quran against disbelievers. On the other hand, a disagreement seemed to arise concerning verse 9:5 and whether this verse counteracts all tolerant, peaceful, and restrained verses (Spencer, 2005). This verse was viewed by some authors in group one and three to abrogate all Quranic verses that impose restrictions regarding jihad, fighting, and the people Muslims should fight (Rabil, 2014; Bartal, 2015; Gorka, 2016; Kilpatrick, 2016; Firestone, 1999; Bonney, 2004; Spencer, 2005), while other authors argued that this verse is a kind of final statement rejecting any kind of discussion of the idea that Islam is a religion of peace and acceptance of others (The Royal Aal Al-Bayt, 2009; Amin, 2015).

\subsubsection{Example five (misinterpretation and mistranslation):}

For example, a verse cited by Bonney (2004) (Group Three) presented the limitation of mistranslating of the word "jahidu" in a war sense, interpreting it as fighting and striving during war:

verse (61:11) "That you believe in Allāh and His Messenger and that you strive hard and fight in the Cause of Alläh with your wealth and your lives..."(Bonney, 2004: 13).

However, the word fight does not exist in the original verse; the sense of jihad in the original text presents a general and comprehensive inclusion of both the spiritual and physical aspects of striving (twojahido). According to Ibn Katheer, Allah offers a trade that never fails, that is, striving hard for Him and against oneself in a self-controlled effort to be a good person, which is better than striving for the evanescent life. Thus, Bonney's restriction of the translation of jihad in this verse to simply it to fighting and war causes a misconception. Moreover, most areas cited as jihadi verses contained words other than jihad, such as "qital," "fight," "kill," and "wage war." Almost no verses, except for 9:19-20 and 61:11, use the word jihad or its derivatives, but in the literature examined, these verses were still understood and treated as parallel to jihad, therefore grouping them into the total number of jihad verses (Rabil, 2014; Bruke, 2017; Evans \& Johnston, 2015; Spencer, 2015; Spencer, 2005; Firestone, 1999; Turner, 2014; Sheindlin, 2015; Ostovar, 2016; Flannery, 2015; Gorka, 2016; Kilpatrick, 2016; Bonney, 2004). 


\subsubsection{Example six (selective quotation leads to misinterpretation and mistranslation):}

Further to the above mistranslations, verse 9:29 was selectively quoted by Evans and Johnston as follows:

"...fight those who do not believe in Allah...and do not forbid what Allah and His Messenger have forbidden" (Evans \& Johnston, 2015: 81). While the whole verse reads as "Fight those who believe not in Allah nor the Last Day, nor hold that forbidden which hath been forbidden by Allah and His Messenger, nor acknowledge the religion of Truth, (even if they are) of the People of the Book, until they pay the Jizya with willing submission, and feel themselves subdued".

This selective quotation gives a distortion of its context, thus presenting the idea that Allah commands Muslims to fight non-Muslims unconditionally and indiscriminately. The authors' incomplete quotation did not make mention of the people to which it alluded, the Jews of Medina, who, in Prophet Muhammad's era, lived within the Islamic state without following the guidance and orders of Allah in their books, in addition to plotting against Muslims (Maudoodi \& Ansari, 2009).

\subsubsection{Example seven (selective quotation and out of context leads to misinterpretation and} mistranslation):

Verse 8:6o was also misquoted in Spencer's book, as follows:

"... make ready your strength to the utmost of your power, including steeds of war, to strike terror into the enemies of Allah" (Spencer, 2015; 42). "Strike terror into the hearts of the enemies of Allah" was further frequently misquoted in this book (Ibid, 43, 50, 51, 66, 107, 165).

The same verse was also a subject of discussion in both of Spencer's (2005; 2015) books along with authors in group one, due to its abuse by radicals such as Zawahiri and Zarqawi, who selectively quoted only, "Make ready your strength to the utmost of your power, including steeds of war, to strike terror into the enemies of Allah" (8:6o), to legitimize the spreading of terror upon those who radicals call "Crusaders and whoever helps them" (Spencer, 2015; Sekulow, 2017; Ostovar, 2017; Evans \& Johnston, 2015). According to Ibn Katheer, verse 8:6o refers to the Banu Quraizah and Persians and could be a reference to hypocrites at that time. All states need to obtain the power to protect themselves and decrease the possibility of outside aggression, and the state of Islam is no exception. Thus, Allah ordered Muslims to make suitable preparations to gain power so that enemies would be fearful of transgressing against them and they could, therefore, prevent potential warfare. Only in the case of war are Muslims allowed to defend themselves and to fight back against aggressors.

\subsubsection{Example eight (misinterpretation and mistranslation):}

Verse 9:111 was also a subject of misinterpretation by Spencer (2005) and Evans and Johnston (2015). Spencer (2005: 35, 110,114) argued that jihad, in a violent sense, is the main duty of a Muslim, and thus, "Paradise is guaranteed to those who 'slay and are slain' for Allah:

'Allah hath purchased of the believers their persons and their goods; for theirs (in return) is the garden (of Paradise): they fight in His cause, and slay and are slain: a promise binding on Him in truth' (Qur'an 9:111)" (Ibid: 35).

In Spencer's 2015 book, he cited the verse three times (Ibid: 36, 42, 158) in the context of ISIS and radicalism, thus reflecting a misinterpretation of how radical mindsets proves that Islam urges violence. He argued that the verse presents a justification in Islamic law for killing and being killed in the name of fighting non-Muslims. In his discussion, Spencer (2015) also claimed that this verse presents a call for young Muslims to engage in a fight against non-Muslims in general, and, in 
particular, a motivation for them to join radical groups that promote and undertake attacks against non-Muslims. Moreover, Spencer (2015) mentioned that Zarqawi "[took] for granted that suicide attacks were permissible" (Ibid: 42) and believed that those who undertake this kind of attack would be rewarded with Paradise. ISIS leader Al-Baghdadi also stated that Paradise is granted for those who kill or are killed in their violent operations, urging his followers for more fighting and attacks (Spencer, 2015). The same point was rearticulated by Evans and Johnston, who argued that devoted Muslims primarily prioritize jihad and hence Paradise is afforded to those who "kill and are killed (Qur'an 9.111)" (Evans \& Johnston, 2015: 97). According to Spencer, this verse stipulates that only those who kill and are killed in the name of Allah will enter Paradise, that is, in terms of ISIS ideology, those who conduct attacks against the West, urging jihadis to kill people and commit suicide bombings(Spencer, 2005; Evans \& Johnston, 2015). Verses like 9:111 are popularly abused to encourage more young men to engage in ISIS' brutal acts and commit crimes in the name of Allah, producing a distorted public image of Islamic principles and their law of war.

To conclude, the above examples where the verses were taken either out-of-context, or selective quotation of Quranic verses yielded misinterpretations of their meanings, either by the authors themselves or by radicals who use portions of verses as the basis of their ideologies partially due to misinterpretation and mistranslation of those verses.

Most authors in Group One held negative perceptions about Islam in general, and toward radical Islam in particular, with one of them even calling indirectly for the need to fight against not only ISIS but all Muslims: "Even if the Islamic State were defeated and eradicated, there are Muslims around the world, including in the United States, who share its worldview, motives, and goals. If the caliphate disappears, they will not. And if no one effectively challenges their beliefs, they will continue waging jihad for decades to come" (Spencer, 2005; 243). However, five authors from Group One explained the contextual and the expanded meaning of jihad as shown below:

1) Kathrin Lenz-Raymann (2014) illustrated that "jihad is associated with an unjustly waged war, even though the concept has its origin in the wars Prophet Muhammad fought lawfully in response to aggression and was originally not allowed to be applied against civilians" (Ibid: 72).

2) Nicolas Hénin and Martin Makinson (2015) stated that Syrian prisons, as well as the US army's internment camps in Iraq, were for many effectively a "jihad academy" (Ibid: 43). They indicated that ISIS was not a force created on its own, but rather instigated by the US and the Syrian regime. Further, they identified jihad as "one of Islam's most beautiful concepts. It is the effort, exerted on and for oneself, with the aim of becoming better, improving one's life and striving for a fairer world" (Ibid: 71).

3) Frances Flannery (2016) gave a detailed justification of the "true" Islam and jihad, expressing clearly that ISIS' contemporary actions and attribution of its terrorist activity to Islam are wrong and have subsequently caused global misconceptions of Islam (ibid: 42).

4) Ali Soufan (2017) hoped that his book showed that there is nothing Islamic about terrorism and those who kill on behalf of Al-Qaeda are brutal men who Islam is innocent of.

5) Daniel Byman (2015) did not relate the entire Islamic religion to terrorism, only so-called Islamist organizations.

\section{Discussion and Conclusion}

Most books in Group One featured negative ideas about Islam in general, and radical Islam in particular, partially due to the distorted images and misquotations of Quranic verses on jihad presented by terrorist groups, such as ISIS, and due to the savage attacks, these groups carry out in the name of Islam. The negative attitudes, distorted images, and stereotypes presented by the authors in Group One had begun prior to the rise of ISIS in 2014, as demonstrated by the books in Group Three.

Media can be seen as a weapon with more destructive qualities than it may seem. It is highly 
focused on conflict and crisis content and its angles on events are usually affected by political or third-party influences. Often, the writing of news reports comes under indirect pressure from governmental organizations and political parties to frame and present events in a way that affects an audience's attitude (Gardner, 2001). The media use of translated texts of Quranic verse can also affect the way these verses are understood, due to the lack of an equivalent translation of the Quran. Furthermore, the context in which media cite Quranic verses also has a huge influence on the image of Islam and the teachings of the Quran, depending on the attitude of the specific media towards these concepts (Ittefaq \& Ahmad, 2018; Tan, 2016). For example, the use of war-like verses and partial verses by ISIS-run media and propaganda reflects an overgeneralization of jihad and war-related acts against multiple targets, not necessarily just non-Muslims and, therefore, a misinterpretation of such verses and the Quran as a whole. Hence, the media can render false reflections of the Quran, which are then employed by radicals, and use Quranic translations that do not give the whole context or idea of a verse, which creates even further distortion of the Quran (Alrefai, 2015; Latif \& Munir, 2014; Ittefaq \& Ahmad, 2018).

According to Islamic teaching, Allah identifies the purpose of Islam in the Quran:

"We have not sent (Prophet Muhammad) except as a mercy to all the world" (21:107).

The message that Allah sent with Prophet Muhammad was to achieve mercy on earth, and anything contrary to mercy and justice does not belong to the message of Islam. Islam recognizes that non-Muslims are an essential component of human society; as Allah says,

"And if thy Lord willed, He verily would have made mankind one nation, yet they cease not differing" (11:118)

And all human beings are honored in Islam regardless of their religions:

"We have honored the children of Adam" (17:70).

Islam builds its relations with non-Muslim communities on the rules of justice, as per the verse,

"Allah does not forbid you to be kind and to act justly to those who have neither made war on your religion nor expelled you from your homes. Allah loves the just" (6o:8). Thus, no fighting is needed unless there is an aggressive provocation: "Fight in the way of Allah those who fight against you, but do not aggress. Allah does not love the aggressors" (2:190).

Moreover, a number of initiatives to defend Islam and to clarify its true teachings and values was created such as; KAICIID, 2007 (https://www.kaiciid.org/), Malaysia's policy of Islam Hadhari, 2004 (http://www.islamhadhari.net/), Marrakesh Declaration 2016 (http://www.marrakeshdeclaratio n.org/), and Amman Message, 2004 (https://ammanmessage.com/) among others. Due to time and space restrictions only some examples from Amman Message initiated in Jordan are discussed. Islam denounces and rejects radicalism, extremism, and fanaticism, as denoted by The Amman Message:

"The source of relations between Muslims and others is peace; for there is no fighting [permitted] when there is no aggression. Even then, [it must be done with] benevolence" (Amman Message, 2004; 3).

Whatever the ideological foundation of terrorism, Islam denounces such concepts that are associated with the transgression of human life and causing fear among peaceful civilians. Moreover, The Amman Message also states that

"[the] history [of] extremism has been instrumental in destroying noble achievements in great civilizations," and that, "the tree of civilization withers when malice takes hold and breasts are shut. In 
all its shapes, extremism is a stranger to Islam, which is founded upon equanimity and tolerance. No human whose heart has been illumined by God could be a radical extremist" (Amman Message, 2004; 4).

\section{Limitations}

This research was limited to the most popular books on jihad, ISIS, and the image of Islam, found on the Amazon website, and thus, has not explored the full range of literature on these topics. Furthermore, this study was restricted to one category of data sources and did not include other media, such as newspapers, press analyses, journal articles, magazines, social media, or TV programs.

\section{Recommendations}

This study provides some recommendations for future action. Collaborative efforts and measures must be taken to prevent and decrease the gap between the West and the Islamic and Arabic worlds by promoting the image of moderate Islam, which seeks the peace and security of all human beings around the globe. For example, media campaigns reinforcing the mutual aspects between Islam and other religions should be carried out as a collaboration between concerned authorities in both Western and Islamic nations. Further awareness campaigns about the teachings of Islam and the distorted images and false claims of terrorist groups such as ISIS should also be implemented both locally and internationally.

Larger and more effective peace and awareness initiatives are further required to counter, or at least decrease, the impact of hate speech, which has expanded via social media to give hate groups even greater opportunities than traditional media to increase and organize their own hate crimes. Finally, rational religious dialogue should be initiated among the adherents of both Islam and Christianity based on the mutual ground highlighted by The Common Word, which are the love and the belief of the oneness of God, complete devotion to Him, and the loving of one's neighbors.

\section{References}

Abdulla, R. (2007). Islam, jihad, and terrorism in post-9/11 Arabic discussion boards. Journal of Computer-Mediated Communication, 12(3), 1063-1081.

Ah mad, M. (2011). Moderation in Islam: A conceptual analysis of Wasatiyyah. TAFHIM: IKIM Journal of Islam and the Contemporary World, 4 .

Alrefai, S., (2015). History of Western Image of Islam and Muslims. Review of History and Political Science, 3(1): 135142.

Al-Turabi, H., Sardar, Z., Jamal, M., \& Zuber, M. (1983). The Islamic State. Voices of resurgent Islam, 241.

Amin, E. (2015). Reclaiming Jihad: A Qur'anic Critique of Terrorism. Kube Publishing Ltd.

Ayubi, N., Hashemi, N., \& Qureshi, E. (1995). Islamic State. Encyclopedia of the Modern Islamic World, 320.

Bartal, S. (2015). Jihad in Palestine: Political Islam and the Israeli-Palestinian Conflict. Abingdon: Routledge.

Bonney, R. (2004). Jihad from Qur'an to Bin Laden. New York, NY: Palgrave Macmillan.

Bukar, D. (Ed.). (2017). Islam and the Infidels: The Politics of Jihad, Da'wah, and Hijrah. New Jersey: Routledge.

Bunzel, C. (2017). Jihadism on Its Own Terms. Hoover Institution, 8. Retrieved from https://www.hoover.org

Burke, J. (2017). The new threat: The past, present, and future of Islamic militancy. London: Bodley Head

Byman, D. (2015). Al Qaeda, the islamic state, and the global jihadist movement: what everyone needs to know. What Everyone Needs To Know (R).

Cherney, A., \& Murphy, K. (2019). Support for terrorism: The role of beliefs in jihad and institutional responses to terrorism. Terrorism and Political Violence, 31(5), 1049-1069.

Cockburn, P. (2016). The age of jihad: Islamic State and the great war for the Middle East. Verso Books.

Cohen, E. A. (2017). The big stick: The limits of soft power and the necessity of military force. New York, NY: Basic Books

Collombier, V., \& Roy, O. (Eds.). (2018). Tribes and Global Jihadism. London: Hurst.

Dolliver, M. J., \& Kearns, E. M. (2019). Is It Terrorism?: Public Perceptions, Media, and Labeling the Las Vegas Shooting. Studies in Conflict \& Terrorism, 1-19. 
Euben, R. L., \& Zaman, M. Q. (Eds.). (2009). Princeton readings in Islamist thought: texts and contexts from alBanna to Bin Laden (Vol. 35).

Evans, C. A., \& Johnston, J. J. (2015). Jesus and the Jihadis: Confronting the Rage of ISIS: The Theology Driving the Ideology. Destiny Image Publishers.

Fatoohi, L. (2004). Jihad in the Qur'an: The Truth from the Source. AS Noordeen

Fealy, G. (2013). The Roots of Terrorism in Indonesia: From Darul Islam to Jem'ah Islamiyah. Cornell : Cornell University Press.

Firestone, R. (1999). Jihäd: the origin of holy war in Islam. Oxford: Oxford University Press.

Flannery, F. L. (2015). Understanding Apocalyptic Terrorism: Countering the Radical Mindset. L., N.Y.: Routledge.

Gardner, E. (2001). The role of media in conflicts. In Luc Reychler, and Thania Paffenholz (eds) Peacebuilding: A Field Guide (301-311). Lynne Rienner Publishers.

Gerges, F. A. (2016). A History of ISIS. Princeton: Princeton University Press.

Gorka, S. (2016). Defeating jihad: The winnable war. DC: Regnery Publishing.

Hamid, S. (2016). Islamic exceptionalism: how the struggle over Islam is reshaping the world. New York: St Martin Press.

Hénin, N. (2015). Jihad Academy: The Rise of Islamic State. New Delhi: Bloomsbury Publishing.

Ibn Kathir, I. https://thequranexplorer.com/tafsir/tafsir-ibn-e-kathir

Ittefaq, M., \& Ahmad, T. (2018). Representation of Islam and Muslims On Social Media: A Discourse Analysis of Facebook. Journal of Media Critiques [JMC], 4(13).

Jukko, R. (2019). Christian Martyrs under Islam: Religious Violence and the Making of the Muslim World: by Christian C. Sahner, Princeton NJ and Oxford, Princeton University Press, 2018, 335 pp., \$39.95/£ 30.00 (hardback), ISBN 978-o-691-17910-o.

Kamali, M. H. (2008). The Middle Grounds of Islamic Civilisation: The Qur'ānic Principle of Wasatiyyah. IAIS Journal of Civilisation Studies, 1, 7-40.

Kennedy, H. (2016). Caliphate: The history of an idea. New York: Basic Books.

Kilpatrick, W., (2016). The Politically Incorrect Guide to Jihad. New Jersey: Regnery Publishing.

King Abdullah II bin Al-Hussein, Amman Message, (9 November 2004) Ramadan sermon by Chief Justice Sheikh Iz-al-Din al-Tamimi

Latif, A. and Munir, H., (2014). Terrorism and Jihad, An Islamic Perspective. Journal of Islamic Studies and Culture. 2(1): 69-8o.

Lenz-Raymann, K. (2014). Securitization of Islam: A Vicious Circle: Counter-Terrorism and Freedom of Religion in Central Asia. Transcript Verlag.

Lister, C. R. (2016). The Syrian Jihad: Al-Qaeda, the Islamic state and the evolution of an insurgency. Oxford University Press.

Lyons, J. (2014). Islam through Western Eyes: from the Crusades to the War on Terrorism. Columbia: Columbia University Press

Maher, S. (2016). Salafi-Jihadism: The history of an idea. Oxford: Oxford University Press.

Maudoodi, S. A. A., \& Ansari, Z. I. (2009). Towards understanding the Quran. Leicester [Leicestershire]: Islamic Foundation.

Mešić, M. (2004). The Perception Of Islam And Muslims In The Media And The Responsibility Of European Muslims Towards The Media. Academia. Retrieved from https://s3.amazonaws.com/academia.edu.documents

Moghadam, A. (2017). Nexus of Global Jihad: Understanding Cooperation Among Terrorist Actors. Columbia: Columbia University Press.

Moubayed, S. (2015). Under the black flag: At the frontier of the new jihad. IB Tauris.

Ostovar, A. (2016). Vanguard of the Imam: Religion, Politics, and Iran's Revolutionary Guards. Oxford: Oxford University Press.

Rabil, R. G. (2014). Salafism in Lebanon: From a politicism to transnational jihadism. Washington: Georgetown University Press.

Ramakrishna, K. (2005). Delegitimizing Global Jihadi Ideology in Southeast Asia. Contemporary Southeast Asia, 343-369.

Ridouani, D. (2011). 6. Ruta: revista universitària de treballs acadèmics, Vol. (3)

Rohschürmann, M. (2018). Thomas Hegghammer (Hrsg.): Jihadi Culture: The Art and Social Practices of Militant Islamists. Cambridge: Cambridge University Press.

Sekulow, J. (2017). Unholy Alliance: The Agenda Iran, Russia, and Jihadists Share for Conquering the World. Nashville: Howard Books

Sheindlin, J., (2015). The people Vs Muhammad: Psychological Analysis. J.K. Sheindlin. 
Soufan, A. (2017). Anatomy of Terror: From the Death of bin Laden to the Rise of the Islamic State. New York, London: WW Norton \& Company.

Spencer, R. (2005). The politically incorrect guide to Islam (and the crusades). Washington DC: Regnery Publishing. Spencer, R. (2015). The complete infidel's guide to ISIS. Washington DC: Regnery Publishing.

Stern, J., \& Berger, J. M. (2015). ISIS: The state of terror (Vol. 7). London: William Collins>

Svensson, J. (2019). Computing Qur'ans: A Suggestion for a Digital Humanities Approach to the Question of Interrelations between English Qur'an Translations. Islam and Christian-Muslim Relations, 30(2), $211-229$.

Tan, C. (2016). Media ethics and the coverage of Islam: Some preliminary observations on the British media. Intellectual Discourse, 24(2).

The Royal Aal Al-Bayt Institute for Islamic Thought, (2009). Jihad and The Islamic Law of War. Jordan: Amman: Author.

Tibi, B. (2014). Political Islam, world politics and Europe: from jihadist to Institutional Islamism. L \& NY.: Routledge.

Turner, J. (2014). Religious ideology and the roots of the global Jihad: Salafi Jihadism and international order. New York: Palgrave Macmillan.

Ushama, T. (2014). Is Islam a religion of moderation or extremism? A study of key Islamic teachings. Asian Social Science, $10(8), 184$.

Wright, L. (2016). The Terror Years: From Al-Qaeda to the Islamic State. New York, NY: Knopf.

Yaakub, M. B. B. H., \& Othman, K. B. (2017). A conceptual analysis of wasatiyyah (Islamic moderation-IM) from Islamic knowledge management (IKM) perspective. Revelation and Science, $7(1)$.

Zimmerman, J. C. (2019). ISIS: A History: by Fawaz Gerges, Princeton, Princeton University Press, 2016, 368 pp., \$12.31 (Paperback), ISBN 978-o691175799.

\section{Appendix 1: Amazon ranking for the examined books}

\begin{tabular}{|c|c|c|}
\hline No. & Name of the book & $\begin{array}{c}\text { Amazon } \\
\text { Rating }\end{array}$ \\
\hline \multicolumn{3}{|c|}{ Group one } \\
\hline 1. & Casaca, P., \& Wolf, S. O. (Eds.). (2017). Terrorism Revisited: Islamism, Political Violence and State-Sponsorship. Springer & o \\
\hline 2. & Collombier, V., \& Roy, O. (Eds.). (2018). Tribes and Global Jihadism. Oxford University Press. & o \\
\hline 3. & Bartal, S. (2015). Jihad in Palestine: Political Islam and the Israeli-Palestinian Conflict. Routledge. & o \\
\hline 4. & Cavatorta, F., \& Merone, F. (2016). Salafism after the Arab awakening: contending with people's power (pp. 1-6). Hurst \& Company & o \\
\hline 5. & $\begin{array}{l}\text { Lenz-Raymann, K. (2014). Securitization of Islam: A Vicious Circle: Counter-Terrorism and Freedom of Religion in Central Asia. } \\
\text { transcript Verlag }\end{array}$ & o \\
\hline 6. & Flannery, F. L. (2015). Understanding Apocalyptic Terrorism: Countering the Radical Mindset. Routledge. & 3.4 \\
\hline 7. & Hamm, M. S., \& Spaaij, R. (2017). Age of Lone Wolf Terrorism. Columbia University Press.: & 4 \\
\hline 8. & Hénin, N. (2015). Jihad Academy: The Rise of Islamic State. Bloomsbury Publishing. & 4 \\
\hline 9. & Hardy, R. (2016). The Poisoned Well: Empire and Its Legacy in the Middle East. Oxford University Press & 4 \\
\hline 10. & Byman, D. (2015). Al Qaeda, the Islamic State, and the Global Jihadist Movement: What Everyone Needs to Know & 4.2 \\
\hline 11. & Lister, C. R. (2016). The Syrian Jihad: Al-Qaeda, the Islamic state and the evolution of an insurgency. Oxford University Press. & 4.2 \\
\hline 12. & $\begin{array}{l}\text { De Bellaigue, C. (2017). The Islamic Enlightenment: The Struggle Between Faith and Reason, } 1798 \text { to Modern Times. Liveright } \\
\text { Publishing }\end{array}$ & 4.2 \\
\hline 13. & Kepel, G. (2017). Terror in France: The rise of jihad in the west (Vol. 64). Princeton University Press & 4.3 \\
\hline 14. & Kilcullen, D. (2016). Blood year: The unraveling of Western counterterrorism. Oxford University Press & 4.3 \\
\hline 15. & Burke, J. (2017). The new threat: The past, present, and future of Islamic militancy. & 4.3 \\
\hline 16. & Wright, L. (2016). The Terror Years: From Al-Qaeda to the Islamic State. Vintage & 4.3 \\
\hline 17. & Cockburn, P. (2016). Age of jihad Islamic state and the great war for Middle East. & 4.3 \\
\hline 18. & Sheindlin, J. K. (2015). The People Vs. Muhammad: Psychological Analysis. [Place of publication not identified]: J.K. Sheindlin & 4.3 \\
\hline 19. & Cohen, E. A. (2017). The big stick: The limits of soft power and the necessity of military force. Hachette UK: & 4.4 \\
\hline 20. & Stern, J., \& Berger, J. M. (2015). ISIS: The state of terror (Vol. 7). London: William Collins & 4.4 \\
\hline 21. & $\begin{array}{l}\text { McCants, W., \& McCants, W. F. (2015). The ISIS apocalypse: The history, strategy, and doomsday vision of the Islamic State. } \\
\text { Macmilla }\end{array}$ & 4.4 \\
\hline 22. & $\begin{array}{l}\text { Evans, C. A., \& Johnston, J. J. (2015). Jesus and the Jihadis: Confronting the Rage of ISIS: The Theology Driving the Ideology. Destiny } \\
\text { Image Publishers }\end{array}$ & 4.4 \\
\hline 23. & Cockburn, P. (2016). ISIS: Battling the Menace. Mango Media Inc & 4.5 \\
\hline 24. & Soufan, A. (2017). Anatomy of Terror: From the Death of bin Laden to the Rise of the Islamic State. WW Norton \& Company. & 4.5 \\
\hline 25. & Neumann, P. R. (2016). Radicalized: New jihadists and the threat to the West. IB Tauris & 4.6 \\
\hline 26. & Spencer, R. (2015). The complete infidel's guide to ISIS. Simon and Schuste & 4.6 \\
\hline 27. & Kennedy, H. (2016). Caliphate: The history of an idea. Basic Books. & 4.6 \\
\hline 28. & Sekulow, J. (2017). Unholy Alliance: The Agenda Iran, Russia, and Jihadists Share for Conquering the World. Simon and Schuster & 4.7 \\
\hline 29. & Gorka, S. (2016). Defeating jihad: The winnable war. Regnery Publishing & 4.7 \\
\hline 30. & $\begin{array}{l}\text { Mitchell, J. E., \& Harlow, B. (2016, November). Enhanced interrogation: Inside the minds and motives of the Islamic terrorists trying } \\
\text { to destroy America. Crown Forum }\end{array}$ & 4.7 \\
\hline 31. & Jones, S. G. (2017). Waging Insurgent Warfare: Lessons from the Vietcong to the Islamic State. Oxford University Press. & 4.8 \\
\hline 32. & Ostovar, A. (2016). Vanguard of the Imam: Religion, Politics, and Iran's Revolutionary Guards. Oxford University Press. & 4.8 \\
\hline
\end{tabular}




\begin{tabular}{|c|c|c|}
\hline No. & Name of the book & $\begin{array}{c}\text { Amazon } \\
\text { Rating }\end{array}$ \\
\hline 33. & $\begin{array}{l}\text { Nesser, P. (2018). Islamist Terrorism in Europe. Oxford University Press. Islamist Terrorism in Europe- (Petter Nesser, Oxford } \\
\text { University Press, 2015). }\end{array}$ & 5 \\
\hline 34. & Bukar, D. (Ed.). (2017). Islam and the Infidels: The Politics of Jihad, Da'wah, and Hijrah. Routledge. & 5 \\
\hline 35. & Kilpatrick, W., (2016). The Politically Incorrect Guide to Jihad. Regnery Publishing. & 5 \\
\hline 36. & Rabil, R. G. (2014). Salafism in Lebanon: From a politicism to transnational jihadism. Georgetown University Press. & 5 \\
\hline 37. & Turner, J. (2014). Religious ideology and the roots of the global Jihad: Salafi Jihadism and international order. Springer & 5 \\
\hline & Average rating of G1 & 3.86 \\
\hline \multicolumn{3}{|c|}{ Group Two } \\
\hline 38. & Amin, E. (2015). Reclaiming Jihad: A Qur'anic Critique of Terrorism. Kube Publishing Ltd. & 3.5 \\
\hline 39. & Ahmad, A. (2017). Jihad \& Co.: Black Markets and Islamist Power. Oxford University Press. Gerges, F. A. (2016). A History of ISIS. & 4 \\
\hline 40. & Hamid, S. (2016). Islamic exceptionalism: how the struggle over Islam is reshaping the world. St. Martin's Press. & 4.1 \\
\hline 41. & Shoebat, W., \& Barrack, B. (2013). The Case for Islamophobia: Jihad by the Sword, America's Final Warning. Top Executive Media & 4.1 \\
\hline 42. & Moubayed, S. (2015). Under the black flag: At the frontier of the new jihad. IB Tauris. & 4.2 \\
\hline 43. & $\begin{array}{l}\text { Euben, R. L., \& Zaman, M. Q. (Eds.). (2009). Princeton readings in Islamist thought: texts and contexts from al-Banna to Bin } \\
\text { Laden (Vol. 35). }\end{array}$ & 4.4 \\
\hline 44. & Maher, S. (2016). Salafi-Jihadism: The history of an idea. Oxford University Press. & 4.5 \\
\hline 45. & Gerges, F. A. (2016). A History of ISIS. & 4.5 \\
\hline 46. & Moghadam, A. (2017). Nexus of Global Jihad: Understanding Cooperation Among Terrorist Actors. Columbia University Press. & 4.6 \\
\hline 47. & Fatoohi, L. (2004). Jihad in the Qur'an: The Truth from the Source. AS Noordeen & 5 \\
\hline 48. & Tibi, B. (2014). Political Islam, world politics and Europe: from jihadist to Institutional Islamism. Routledge. & 5 \\
\hline 49. & Fealy, G. (2013). The Roots of Terrorism in Indonesia: From Darul Islam to Jem'ah Islamiyah. Cornell University Press. & 5 \\
\hline & Average rating of $\mathrm{G}_{2}$ & 4.41 \\
\hline \multicolumn{3}{|c|}{ Group three } \\
\hline 50. & The Great War for civilization- The Conquest of the Middle East, 2007 Vintage book (Robert Fisk & 3.6 \\
\hline 51. & Jihad: The Origin of Holy War in Islam (Reuven Firestone) 1999 & 3.8 \\
\hline 52. & Jihad: From Quran to bin Laden (Richard Bonney) 2004 & 3.8 \\
\hline 53. & The Looming Tour, Al Qaeda and the Road TO 9/11 (Lawrence Wright),20o6 & 3.9 \\
\hline 54. & The Terror Factory, Inside the FBI'S Manufactured War on Terrorism (Trevor Aaronson)2013 & 4.3 \\
\hline 55. & Inside Terrorism, Revised and Expanded Edition (Bruce Hoffman)2oo6 & 4.4 \\
\hline 56. & The Politically Incorrect Guide to Islam and the Crusades (Robert Spencer) 2005 & 4.6 \\
\hline & Average rating of $\mathrm{G}_{3}$ & 4.06 \\
\hline \multicolumn{3}{|c|}{ Irrelevant books } \\
\hline 57. & Reintegrating Jihadist Extremist Detainees_Helping Extremist Offenders Back into Society (2017, Routledge) & o \\
\hline 58. & Jean-Pierre Filiu - From Deep State to Islamic State (2015, Oxford University Press) & $3 \cdot 3$ \\
\hline 59. & Patrick Cockburn - The Jihadis Return_ ISIS and the New Sunni Uprising (2014, OR Books) & 3.8 \\
\hline 6o. & G.W Bowersock - The Crucible of Islam (2017, Harvard University Press) & 3.9 \\
\hline 61. & Kapur, S. Paul-Jihad as grand strategy__slamist militancy, national security, and the Pakistani state-Oxford University Press (2017) & 4.5 \\
\hline 62. & $\begin{array}{l}\text { Diego Gambetta, Steffen Hertog - Engineers of Jihad_ The Curious Connection between Violent Extremism and Education (2016, } \\
\text { Princeton University Press) }\end{array}$ & 4.6 \\
\hline 63. & Patrick Cockburn - The Rise of Islamic State_ISIS and the New Sunni Revolution (2015, Verso) & 4.6 \\
\hline 64. & Joby Warrick-Black Flags_The Rise of ISIS-Doubleday (2015) & 4.7 \\
\hline 65. & Lyons, J. (2014). Islam through Western Eyes: from the Crusades to the War on Terrorism. Columbia University Press & 4.7 \\
\hline 66. & Thomas Hegghmmer- Jihadi culture, the art and social practices of militant Islamist 2017. & 5 \\
\hline & Average rating of Irrelevant books & 3.91 \\
\hline & Total ratings of all books & 4.0 \\
\hline
\end{tabular}

